\title{
FAKTOR-FAKTOR YANG MEMPENGARUHI AKUNTABILITAS KINERJA INSTANSI PEMERINTAHAN (AKIP)
}

\author{
Suci Indah Sari \\ Fakultas Ekonomi, Universitas Muhammadiyah Riau \\ e-mail: suciindahsaripku2@gmail.com
}

\begin{abstract}
ABSTRAK
Dalam beberapa tahun terakhir penilaian LAKIP pemerintah daerah Kota Pekanbaru masih jauh dari harapan yang diinginkan. Hal ini mencerminkan Pemko Pekanbaru tak cukup baik sebagai cerminan ibu kota Provinsi Riau. Tujuan penelitian ini bertujuan untuk pengaruh kejelasan anggaran, penerapan akuntansi keuangan daerah dan sistem pelaporan terhadap Akuntabilitas Kinerja Instansi Pemerintah Kota Pekanbaru. Populasi dalam penelitian ini adalah seluruh organisasi perangkat daerah (OPD) pada instansi Pemerintah Kota Pekanbaru, yang berjumlah 43 OPD. Pengambilan sampel dalam penelitian ini menggunakan metode Purposive Sampling sehingga diperoleh 129 responden. Jenis data yang diguanakan dalam penelitian ini adalah data primer dengan teknik pengumpulan data menggunakan kuesioner. Analisis data menggunakan regresi linier berganda. Hasil penelitian menunjukkan bahwa kejelasan anggaran berpengaruh terhadap Akuntabilitas Kinerja Instansi Pemerintah, penerapan akuntansi keuangan daerah berpengaruh terhadap Akuntabilitas Kinerja Instansi Pemerintah dan sistem pelaporan berpengaruh terhadap Akuntabilitas Kinerja Instansi Pemerintah
\end{abstract}

Kata Kunci : Kejelasan Anggaran, Penerapan Akuntansi Keuangan Daerah, Sistem Pelaporan, Akuntabilitas Kinerja Instansi Pemerintah

\section{ABSTRACT}

In recent years the LAKIP assessment of the Pekanbaru City government is still far from the desired expectation. This reflects that the Pekanbaru City Government is not good enough as a reflection of the capital city of Riau Province. The purpose of this study aims to influence budget clarity, the application of regional financial accounting and reporting systems on the Performance Accountability of Pekanbaru City Government Agencies. The population in this study were all regional apparatus organizations (OPD) in Pekanbaru City Government agencies, which amounted to 43 OPD. Sampling in this study used the purposive sampling method in order to obtain 129 respondents. The type of data used in this study is primary data with data collection techniques using questionnaires. Data analysis used multiple linear regression. The results of the study indicate that budget clarity affects the Performance Accountability of Government Agencies, the application of regional financial accounting affects the Performance Accountability of Government Agencies and the reporting system affects the Performance Accountability of Government Agencies.

Keywords: budget clarity, application of regional financial accounting, reporting system, Performance Accountability of Government Agencies

\section{PENDAHULUAN}

Menurut Ahyaruddin \& Akbar (2017) Laporan Akuntabiltas Kinerja Instansi Pemerintah (LAKIP) merupakan suatu sistem untuk melakukan pengukuran kinerja yang baik dan memadai. Pengukuran kinerja harus dilakukan secara sistematis dan berkesinambungan agar tercapai pengelolaan organisasi yang optimal, bersih dan bertanggung jawab. Permasalahan yang ditemukan berkaitan dengan judul penelitian yaitu, dalam beberapa tahun terakhir penilaian LAKIP pemerintah daerah Kota Pekanbaru masih jauh dari harapan yang diinginkan. Pada tahun 2015 kota pekanbaru meraih predikat C dengan Nilai 43,15, pada tahun 2016 Kota Pekanbaru masih meraih predikat C dengan Nilai 48,18, pada Tahun 2017 Kota Pekanbaru masih kembali meraih predikat $\mathrm{C}$ dengan Nilai 53,50, Pada tahun 2018 Kota Pekanbaru mengalami peningkatan 1,18\% dengan nilai 54,68 dengan predikat CC, Tahun 2019, naik 4 poin menjadi 58 tetapi masih dengan predikat 
CC. Hal ini mencerminkan Pemko Pekanbaru tak cukup baik sebagai cerminan ibu kota Provinsi Riau (Berita Pemko, 2020). Seperti dikutip dari https://riaupos.jawapos.com/, Nilai CC yang didapat Pemko Pekanbaru menunjukkan masih terjadi inefisiensi sebesar 30 persen dalam akuntabilitas kinerja. Banyak indikator yang tidak selaras selama ini, Indikator ini adalah Rencana Pembangunan Jangka Menengah Daerah (RPJMD) yang merupakan penjabaran dari visi, misi, dan program kepala daerah tidak selaras sampai pada pelaksanaan program kerja dan kegiatan OPD yang ada di Pemko Pekanbaru. Faktor utamanya RPJMD harus dilakukan perubahan. Karena RPJMD tidak mendukung visi dan misi kepala daerah terpilih,' penilaian yang rendah terjadi karena hasil kegiatan tidak jelas ukurannya. Ini terjadi karena tidak jelas hasil yang dicapai. Ukuran kinerja tidak jelas. Tidak ada keterkaitan program dengan sasaran. Rincian kegiatan tidak sesuai dengan hasil kegiatan. Berdasarkan informasi tersebut dapat diketahui bahwa rendahnya nilai yang AKIP yang dioeroleh Kota Pekanbaru disebabkan karena hasil kegiatan yang tidak jelas, ukuran kinerja tidak jelas, tidak ada keterkaitan program dengan sasaran. Rincian kegiatan tidak sesuai dengan hasil kegiatan. Untuk itu penulis mengambil beberapa faktor yang dapat mempengaruhi kinerja akuntabilitas instansi pemerintah. Diantaranya yang masih berkaitan dengan penyebab rendahnya nilai AKIP yang diperoleh yaitu kejelasan sasaran anggaran, penerapan akuntansi keuangan daerah dan sistem pelaporan.

Faktor-faktor yang mempengaruhi akuntabilitas kinerja instansi pemerintahan diantaranya adalah kejelasan sasaran anggaran penerapan akuntansi keuangan daerah dan sistem pelaporan. Menurut Khairunsyah \& Yulia (2018) Kejelasan sasaran anggaran adalah salah satu cara yang yang dilakukan untuk menggambarkan luasnya suatu sasaran yang jelas dan dapat dimengerti oleh pihak yang bertanggung jawab atas pencapaiannya. Beberapa hasil penelitian sebelumnya menemukan, Cantika (2018) menyatakan bahwa kejelasan sasaran anggaran berperngaruh secara signifikan terhadap Akuntansi Kinerja Instansi Pemerintahan (AKIP). Namun hal berbeda yang dinyatakan oleh Darwanis \& Chairunnisa (2013) menyatakan bahwa kejelasan anggaran tidak berperngaruh seacara signifikan terhadap Akuntansi Kinerja Instansi Pemerintahan (AKIP). Adapun faktor lain yang mempengaruhi akuntabilitas kinerja instansi pemerintahan adalah penerapan akuntansi keuangan daerah. Dengan dilakukannya panerapan akuntnsi keuangan merupakan salah satu cara untuk mempermudah pihak - pihak yang membutuhkan laporan keuangan yang mana laporan tersebut telah sesuai dengan Standar Akuntansi Keuangan (SAK). Adapun beberapa penelitian sebelumnya menemukan, Zulfiandri (2017) menyatakan bahwa penerapan akuntansi keuangan daerah berpengaruh signifikan terhadap Akuntansi Kinerja Instansi Pemerintahan (AKIP). Namun berbeda dengan Pratiwi \& Setyowati (2017) menyatakan bahwa penerapan akuntansi keuangan daerah tidak berpengaruh signifikan terhadap Akuntansi Kinerja Instansi Pemerintahan (AKIP).

Faktor selanjutnya adalah sistem pelaporan. Sistem pelaporan merupakan refleksi kewajiban untuk merepresentasikan dan melaporkan kinerja semua aktivitas dan sumberdaya yang perlu dipertanggungjawabkan (Nordiawan, 2010). Pemerintah berkewajiban untuk memberikan informasi keuangan dan informasi lainnya yang akan digunakan untuk pengambilan keputusan ekonomi, sosial, dan politik oleh pihak-pihak yang berkepentingan. Sistem pelaporan yang baik sangat diperlukan agar dapat memantau dan mengendalikan kinerja manejerial dalam mengimplementasikan anggaran yang telah ditetepkan, serta mampu memberikan informasi yang akurat, relevan, tepat waktu, konsisten serta dapat dipercaya dan dipertanggungjawabkan. Dengan adanya sistem pelaporan yang baik akan mampu memberikan umpan balik (feedback) untuk mengukur pelaksanaan rencana atau pencapaian sasaran anggaran yang ditetapkan terhadap suatu kegiatan sehingga dapat meningkatkan akuntabilitas kinerja di suatu instantsi. Dalam penelitaan yang dilakukan Suyanto (2015) menunjukkan bahwa sistem pelaporan berpengaruh positif dan signifikan terhadap akuntabilitas kinerja instansi pemerintah. Dengan adanya sistem pelaporan yang baik akan mampu menyajikan informasi secara akurat, akuntabel dan lebih transparan mengenai keputusan yang akan diambil dalam suatu periode. Namun bertolak belakang dengan penelitian Nurji dan Asmoni (2019) yang menyatakan Sistem Pelaporan tidak berpengaruh terhadap Akuntabilitas Kinerja Instansi Pemerintah.

Penelitian ini pengembangan dari penelitian yang dilakukan oleh Mulyadi et,al (2018) yang berjudul Pengaruh Sisitem Pelaporan dan Kejelasan Sasaran Anggaran Terhadap Akuntabilitas kinerja Instansi Pemerintah. Namun ada beberapa hal yang membedakan penelitian ini dengan penelitian sebelumnya adalah pada penelitian sebelumnya, variabel yang digunakan adalah Sistem Pelaporan dan Kejelasan Sasaran Anggaran sedangkan pada penelitian ini menambahkan variabel yaitu penerapan akuntansi keuangan daerah. 
Kemudian lokasi penelitian, dimana penelitian terdahulu dilakukan pada SKPD Aceh, sedangkan penelitian ini dilakukan pada Pemerintah Kota Pekanbaru.

\title{
TINJAUAN LITERATUR DAN PERUMUSAN HIPOTESIS
}

\section{Stewardship Theory}

Grand theory yang mendasari penelitian ini adalah stewardship theory (Donaldson dan Davis, 1991), Implikasi teori stewardship terhadap penelitian ini, dapat menjelaskan eksistensi Pemerintah Daerah sebagai suatu lembaga yang dapat dipercaya untuk bertindak sesuai dengan kepentingan publik dengan melaksanakan tugas dan fungsinya dengan tepat.

\begin{abstract}
Akuntabilitas Kinerja Instansi Pemerintah
Mardiasmo (2012) mengartikan akuntabilitas sebagai hubungan antara pihak yang memegang kendali dan mengatur entitas dengan pihak yang memiliki kekuatan formal atas pihak pengendali tersebut
\end{abstract}

\section{Kejelasan Sasaran Anggaran}

Menurut Mardiasmo (2012) anggaran merupakan target kinerja yang ingin dicapai selama waktu periode tertentu, anggaran juga merupakan artikulasi dari hasil pereumusan strategi dan perencanaan strategi yang telah dibuat serta memfasilitasi agar tercapainya tujuan dari organisasi tersebut.

\section{Penerapan Akuntansi Keuangan Daerah}

Menurut Zulfiandri (2017) penerapan akuntansi keuangan daerah sangat membantu bagi instansi pemerintahan untuk membuat laporan keuangan menjadi lebih baik, dan hal ini akan memberikan dampak meningkatnya akuntabilitas kinerja instansi pemerintah daerah.

\section{Sistem Pelaporan}

Menurut Bastian (2014) sistem pelaporan kinerja merupakan refleksi kewajiban untuk mempresentasikan dan melaporkan kinerja semua aktivitas serta sumber daya yang harus dipertanggungjawabkan

\section{Pengaruh Kejelasan Sasaran Anggaran Pada Akuntabilitas Kinerja Instansi Pemerintahan (AKIP).}

Kejelasan sasaran anggaran merupakan tujuan utama disebuah organisasi ataupun instansi pemerintah. Bagi pemrintahan daerah kejelasan sasaran anggaran merupakan hal yang penting agar bisa mendapatkan kepercayaan dari mamasyarakat atas dana anggaran yang akan dikelola oleh pemerintahaan daerah. Karena dana anggaran menjadi persoalan yang sangat sensitif apabila dana anggaran tersebut salah dalam pengelolaannya. Berdasarkan teori stewardship, Pemerintah selaku steward dengan fungsi pengelola sumber daya dan rakyat selaku principal pemilik sumber daya. Terjadi kesepakatan yang terjalin antara pemerintah (steward) dan rakyat (principal) berdasarkan kepercayaan, kolektif sesuai tujuan organisasi. Dalam konteks organisasi sektor publik akuntabilitas merupakan kewajiban pemerintah sebagai pemegang amanah (steward) untuk mempertanggungjawabkan kegiatannya kepada rakyat sebagai pihak pemberi amanah (principal) dengan mengungkap segala informasi, baik keberhasilan maupun kegagalan yang dialami oleh organisasi tersebut. Organisasi sektor publik memiliki tujuan memberikan pelayanan kepada publik dan dapat di pertanggungjawabkan kepada masyarakat (publik).(Yusmaniarti, 2014)

Kejelasan sasaran anggaran berimplikasi pada pimpinan, untuk menyusun anggaran sesuai dengan sasaran yang ingin dicapai instansi pemerintah. Pimpinan akan memiliki informasi yang cukup untuk memprediksi masa depan yang tepat. Sasaran yang jelas akan mempermudah OPD untuk menyusun target anggaran. Selanjutnya target target anggaran yang disusun akan sesuai dengan sasaran yang akan dicapai pemerintah. Oleh karena itu, kinerja sendiri merupakan hasil akhir (output) organisasi yang sesuai dengan tujuan organisasi

\section{H1 : Kejelasan Sasaran Anggaran Berpengaruh Terhadap Akuntabilitas Kinerja Instansi Pemerintahan (AKIP)}




\section{Pengaruh Penerapan Akuntansi Keuangan Daerah Pada Akuntabilitas Kinerja Instansi Pemerintahan} (AKIP).

Penerapan akuntansi keuangan daerah yang baik adalah laporan yang mengikuti SAP. Jika laporan itu dibuat tidak sesuai dengan standar dan ketentuan yang telah ditetapkan maka laporan itu dapat di mengerti oleh orang. Bagi pemerintah laporan itu adalah hal yang sangat penting karena dengan adanya laporan maka pemerintah akan dengan mudah melihat perkembangan yang terjadi. Laporan yang dimaksud adalah laporan yang sedang terjadi dan laporan keuangan. Laporan itu dapat kita jumpai dari media sosial, media masa dan dari orang yang bersangkutan langsung. Selain itu menurut pandapat Nordiawan (2006) SAP diterapkan di lingkup pemerintahan, baik di pemerintah pusat dan departemen-departemennya ataupun di pemerintahan daerah dan dinasnya. Penerapan SAP diyakini akan berdampak pada peningkatan kualitas pelaporan keuangan di pemerintahan pusat dan daerah. Oleh karena itu penerapan SAP diyakini akan berdampak pada peningkatan kualitas pelaporan keuangan di pemerintahan pusat dan daerah. Dengan demikian informasi keuangan pemerintahan akan dapat menjadi dasar pengambilan keputusan di pemerintahan dan juga terwujudnya transparansi serta akuntabilitas.

Dalam teori stewardship, manajemen pemerintahan dituntut untuk memberikan pelayanan (bertindak sebagai steward (pelayan) bagi kepentingan principal. Dengan demikian manajemen di lingkungan pemerintahan lebih dominan bertindak sebagai steward dibandingkan sebagai agent. implikasi dari teori stewardship yaitu bagaimana pemerintah diberikan kepercayaan dalam melakukan tugas dan fungsinya dengan tepat, merencanakan dan melaksanakan fungsi pemerintahan secara maksimal. Untuk melaksanakan tanggungjawab tersebut ka stewards diharapkan mengerahkan semua kempuan dan sumber daya guna mencapai kinerja yang diharapkan organisasi.

\section{H2 : Penerapan Akuntansi Keuangan Daerah Berpengaruh Terhadap Akuntabilitas Kinerja Instansi Pemerintahan (AKIP)}

\section{Pengaruh Sistem Pelaporan terhadap Akuntabilitas Kinerja Instansi Pemerintahan (AKIP).}

Sistem pelaporan diperlukan dalam pertanggungjawaban pengelolaan sumber daya tersebut dengan baik untuk mencapai kinerja yang diharapkan oleh masyarakat dan untuk menciptakan akuntabilitas terhadap masyarakat. Sistem pelaporan merupakan laporan yang menggambarkan sistem pertanggungjawaban dari bawahan (pimpinan unit anggaran) kepada atasan (kepala bagian anggaran).

Teori stewardship menjelaskan eksistensi Pemerintah Daerah sebagai suatu lembaga yang dapat dipercaya untuk bertindak sesuai dengan kepentingan publik dengan melaksanakan tugas dan fungsinya dengan tepat, bertindak secara ekonomis dan efisien dalam penfaatan sumber daya, membuat pertanggungjawaban yang dianahkan kepadanya, sehingga tujuan ekonomi, pelayanan publik upun kesejahteraan masyarakat dapat tercapai secara maksimal. Untuk melaksanakan tanggungjawab tersebut maka stewards dapat menerapkan anggaran berbasis kinerja, mengarahkan semua kempuan dan keahliannya serta menerapkan kepemimpinan yang efektif untuk dapat meningkatkan akuntabilitas kinerja instansi pemerintah. Sistem pelaporan yang baik sangat diperlukan agar dapat memantau dan mengendalikan kinerja manejerial dalam mengimplementasikan anggaran yang telah ditetepkan, serta mampu memberikan informasi yang akurat, relevan, tepat waktu, konsisten serta dapat dipercaya dan dipertanggungjawabkan. Putra (2017) berpendapat bahwa pelaporan yang baik pada pengelolaan keuangan daerah dapat mempengaruhi peningkatan akuantabilitas kinerja instansi pemerintah.

\section{H3 : Sistem Pelaporan Berpengaruh Terhadap Akuntabilitas Kinerja Instansi Pemerintahan (AKIP).}

\section{Kerangka Pemikiran}




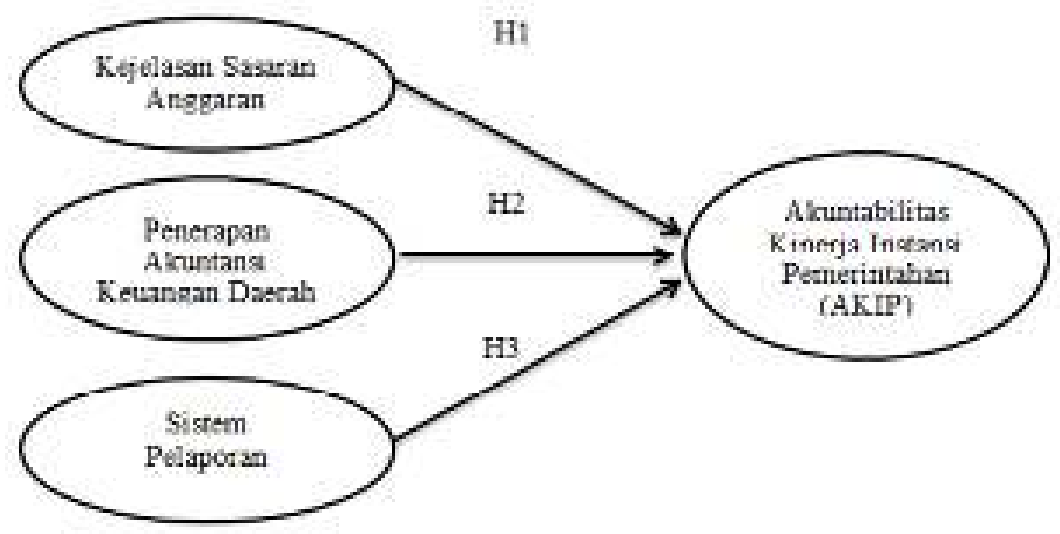

Gambar 1. Kerangka Pemikiran

\section{METODE PENELITIAN}

Penelitian ini merupakan jenis penelitian ini adalah kuntitatif. Populasi dalam penelitian ini adalah seluruh organisasi perangkat daerah (OPD) pada instansi Pemerintah Kota Pekanbaru, yang berjumlah 43 OPD. Pengambilan sampel dalam penelitian ini menggunakan metode Purposive Sampling, Sampel adalah pegawai yang bertugas menyusun laporan keuangan di masing-masing OPD di Kota Pekanbaru, yang terdiri dari, Kepala Sub Bagian Keuangan dan Staf Bagian Keuangan, sedangkan di Kecamatan, Sekertaris Camat, Kepala Sub Bagian Keuangan. dan staf keuangan, sehingga diperoleh 129 rsponden. Jenis data yang diguanakan dalam penelitian ini adalah data primer. Adapun teknik pengumpulan data yang digunakan dalam penelitian ini adalah kuesioner (Angket). Analisis data menggunakan regresi linier berganda.

\section{HASIL DAN PEMBAHASAN}

Kuesioner disampaikan pada responden disertai surat permohonan untuk menjadi responden dan penjelasan mengenai tujuan penelitian. Penyebaran kuesioner dilakukan pada Bulan Juli 2021. Kuesioner yang disebarkan yaitu sebanyak 129 eksemplar, Adapun sampel dan tingkat pengembalian kuisioner dapat dilihat pada Tabel 1

Tabel 1.Tingkat Pengembalian Kuisioner

\begin{tabular}{lcc}
\hline \multicolumn{1}{c}{ Keterangan } & Total & Persentase \\
\hline Kuesioner yang disebar & 129 & $100 \%$ \\
Kuesioner yang tidak kembali & 30 & $23,3 \%$ \\
Kuesioner yang kembali & 99 & $76,7 \%$ \\
Kuesioner yang dapat diolah & 99 & $76,7 \%$ \\
\hline
\end{tabular}

Sumber: Data Olahan (2021)

Berdasarkan Tabel 1 dapat dijelaskan bahwa penelitian ini telah menyebarkan 129 kuesioner kepada OPD di Kota Pekanbaru dengan pengembalian kuesioner 76,7 \% atau sebanyak 99 kuesioner yang dapat diolah.

\section{Hasil Analisis Deskriptif Variabel Penelitian}


Tabel 2. asil Uji Statistik Deskriptif Variabel Penelitian Descriptive Statistics

\begin{tabular}{lrrrrr}
\hline & N & Minimum & Maximum & Mean & Std. Deviation \\
\hline AKIP (Y) & 99 & 3,00 & 5,00 & 3,81 & 0,61550 \\
Kejelasan Sasaran (X1) & 99 & 3,29 & 4,86 & 4,08 & 0,40247 \\
Penerapan Akuntansi (X2) & 99 & 3,13 & 4,88 & 4,05 & 0,43925 \\
Sistem Pelaporan (X3) & 99 & 3,00 & 5,00 & 3,93 & 0,49609 \\
Valid N (listwise) & 99 & & & & \\
\hline
\end{tabular}

\section{Sumber: Data Olahan (2021)}

Berdasarkan Tabel 2 di atas dapat dijelaskan statistik deskriptif masing-masing variabel sebagai berikut.

1. Akuntabilitas Kinerja Instansi Pemerintah memilikirata-rata 3,81 yang berarti bahwa Akuntabilitas Kinerja Instansi Pemerintah di Kota Pekanbaru sudah baik

2. Kejelasan Sasaran Anggaran memiliki rata-rata 4,08 yang berarti bahwa kejelasan sasaran anggaran di Kota Pekanbaru sudah baik.

3. Kejelasan Sasaran Anggaran,memiliki rata--rata 4,08 yang berarti bahwa penerapan akuntansi keuangan pemerintah di Kota Pekanbaru sudah baik

4. Sistem Pelaporan memiliki rata-rata 3,93 yang berarti bahwa sistem pelaporan di Kota Pekanbaru sudah baik.

\section{Hasil Uji Validitas Variabel Penelitian}

Akuntabilitas Kinerja Instansi Pemerintah pada penelitian ini terdiri dari 10 item pernyataan. Adapun hasil uji validitas variabel Akuntabilitas Kinerja Instansi Pemerintah dapat dilihat pada Tabel 3

Tabel 3. Hasil Uji Validitas Data Akuntabilitas Kinerja Instansi Pemerintah

\begin{tabular}{|c|c|c|c|}
\hline Butir Pernyataan & r hitung & $r$ tabel & Keterangan \\
\hline \multicolumn{4}{|c|}{ Akuntabilitas Kinerja Instansi Pemerintah } \\
\hline Y.1 & 0.315 & 0,1975 & Valid \\
\hline Y.2 & 0.533 & 0,1975 & Valid \\
\hline Y.3 & 0.458 & 0,1975 & Valid \\
\hline Y.4 & 0.510 & 0,1975 & Valid \\
\hline Y.5 & 0.484 & 0,1975 & Valid \\
\hline \multicolumn{4}{|c|}{ Kejelasan Sasaran Anggaran } \\
\hline X1.1 & 0.295 & 0,1975 & Valid \\
\hline X1.2 & 0.365 & 0,1975 & Valid \\
\hline $\mathrm{X} 1.3$ & 0.507 & 0,1975 & Valid \\
\hline $\mathrm{X} 1.4$ & 0.605 & 0,1975 & Valid \\
\hline $\mathrm{X} 1.5$ & 0.560 & 0,1975 & Valid \\
\hline $\mathrm{X} 1.6$ & 0.359 & 0,1975 & Valid \\
\hline $\mathrm{X} 1.7$ & 0.448 & 0,1975 & Valid \\
\hline \multicolumn{4}{|c|}{ Penerapan Akuntansi Keuangan Daerah } \\
\hline $\mathrm{X} 2.1$ & 0.488 & 0,1975 & Valid \\
\hline $\mathrm{X} 2.2$ & 0.565 & 0,1975 & Valid \\
\hline $\mathrm{X} 2.3$ & 0.610 & 0,1975 & Valid \\
\hline $\mathrm{X} 2.4$ & 0.546 & 0,1975 & Valid \\
\hline $\mathrm{X} 2.5$ & 0.539 & 0,1975 & Valid \\
\hline $\mathrm{X} 2.6$ & 0.634 & 0,1975 & Valid \\
\hline $\mathrm{X} 2.7$ & 0.591 & 0,1975 & Valid \\
\hline $\mathrm{X} 2.8$ & 0.327 & 0,1975 & Valid \\
\hline
\end{tabular}




\begin{tabular}{cccc}
\hline Sistem Pelaporan & & & \\
\hline X3.1 & 0.511 & 0,1975 & Valid \\
X3.2 & 0.658 & 0,1975 & Valid \\
X3.3 & 0.442 & 0,1975 & Valid \\
\hline
\end{tabular}

\section{Sumber: Data Olahan (2021)}

Dari tabel di atas terlihat bahwa masing-masing butir pernyataan di atas kriteria 0,1975 ( $\mathrm{r}$ tabel). jadi dapat disimpulkan bahwa secara statistik masing-masing indikator pernyataan untuk variabel sistem pelaporan adalah valid dan layak untuk digunakan sebagai data penelitian.

\section{Hasil Uji Reliabilitas Data}

Tabel 4. Hasil Uji Reliabilitas Data

\begin{tabular}{lccc}
\hline \multicolumn{1}{c}{ Variabel } & Standar & $\begin{array}{c}\text { Cronbach's } \\
\text { Alpha }\end{array}$ & Keterangan \\
\hline AKIP (Y), & 0,70 & 0,701 & Reliabel \\
Kejelasan Sasaran (X1), & 0,70 & 0,732 & Reliabel \\
Penerapan Akuntansi (X2) & 0,70 & 0,814 & Reliabel \\
Sistem Pelaporan (X3) & 0,70 & 0,713 & Reliabel \\
\hline
\end{tabular}

Sumber: Data Olahan (2021)

Berdasarkan di atas dapat dilihat bahwa koefisien reliabilitas instrumen Akuntabilitas Kinerja Instansi Pemerintah (Y), Kejelasan sasaran anggaran (X1), Penerapan Akuntansi Keuangan Pemerintah (X2) dan Sistem pelaporan (X3), menunjukkan bahwa koefisien Cronbach Alpha> 0,70 sehingga dapat disimpulkan bahwa semua instrumen dalam penelitian ini adalah reliabel.

\section{Hasil Uji Normalitas Data}

Tabel 5. Hasil Uji Normalitas Data

\begin{tabular}{llr}
\hline \multicolumn{2}{c}{ One-Sample Kolmogorov-Smirnov Test } \\
\hline & & $\begin{array}{c}\text { Unstandardized } \\
\text { Residual }\end{array}$ \\
\hline $\mathrm{N}$ & & 99 \\
Normal Parameters & & \\
& Mean & .0000000 \\
Most Extreme & Std. Deviation & 1.07477754 \\
Differences & Absolute & .080 \\
& Positive & .080 \\
Test Statistic & Negative & -.042 \\
Asymp. Sig. (2-tailed) & & .080 \\
Sumber: Data Olahan (2021) & $.127^{\mathrm{c}}$ \\
\hline
\end{tabular}

Dari tabel di atas dapat dilihat bahwa nilai Asymp. Sig. sebesar 0,127 $>0,05$. Sehingga dapat disimpulkan bahwa persyaratan uji normalitas dapat terpenuhi untuk pengujian hipotesis. 


\section{Hasil Uji Multikolinearitas}

Tabel 6. Hasil Uji Multikolinearitas

\begin{tabular}{llcc}
\hline & & \multicolumn{2}{c}{ Collinearity Statistics } \\
\cline { 3 - 4 } Model & & Tolerance & VIF \\
\hline 1 & (Constant) & & \\
& Kejelasan Sasaran (X1) & 0.324 & 3.083 \\
& Penerapan Akuntansi (X2) & 0.764 & 1.308 \\
& Sistem Pelaporan (X3) & 0.347 & 2.883 \\
\hline
\end{tabular}

Dari tabel di atas, dapat dilihat bahwa VIF untuk seluruh variabel bebas $<10$ dan begitu juga nilai tolerance $>0,10$. Hal ini dapat disimpulkan bahwa model regresi tersebut bebas dari multikolinearitas..

\section{Hasil Uji Heterokedastisitas}

Tabel 7. Hasil Uji Heterokedastisitas (Uji Glejser)

\begin{tabular}{|c|c|c|c|c|c|}
\hline \multirow[b]{3}{*}{ Model } & \multicolumn{3}{|c|}{ Coefficients $^{\mathrm{a}}$} & \multirow[b]{3}{*}{$\mathrm{t}$} & \multirow[b]{3}{*}{ Sig. } \\
\hline & $\begin{array}{r}\text { Unsta } \\
\mathrm{Coe}\end{array}$ & $\begin{array}{l}\text { dardized } \\
\text { icients }\end{array}$ & $\begin{array}{l}\text { Standardized } \\
\text { Coefficients }\end{array}$ & & \\
\hline & B & Std. Error & Beta & & \\
\hline 1 (Constant) & 1.212 & .762 & & 1.591 & .115 \\
\hline Kejelasan Sasaran (X1) & -.008 & .043 & -.034 & -.189 & .850 \\
\hline Penerapan Akuntansi (X2) & -.004 & .054 & -.008 & -.072 & .943 \\
\hline Sistem Pelaporan (X3) & -.003 & .034 & -.014 & -.082 & .935 \\
\hline
\end{tabular}

a. Dependent Variable: ABS

Berdasarkan hasil uji glejser diatas dapat dilihat bahwa keseluruhan variabel memiliki nilai sig $>0,05$, sehingga dapat disimpulkan tidak terdapat heteroskedastisitas dalam penelitian ini.

\section{Hasil Uji Regresi Linier Berganda}

Tabel 8. Hasil Uji Regresi Linier Berganda

\section{Coefficients $^{\mathrm{a}}$}

\begin{tabular}{|c|c|c|c|c|c|c|}
\hline \multirow{2}{*}{\multicolumn{2}{|c|}{ Model }} & \multicolumn{2}{|c|}{$\begin{array}{l}\text { Unstandardized } \\
\text { Coefficients }\end{array}$} & \multirow{2}{*}{$\begin{array}{c}\begin{array}{c}\text { Standardized } \\
\text { Coefficients }\end{array} \\
\text { Beta }\end{array}$} & \multirow[b]{2}{*}{$\mathrm{t}$} & \multirow[b]{2}{*}{ Sig. } \\
\hline & & $\mathrm{B}$ & Std. Error & & & \\
\hline \multirow[t]{4}{*}{1} & (Constant) & .053 & 1.235 & & .043 & .966 \\
\hline & Kejelasan Sasaran (X1) & 401 & .070 & .520 & 5.693 & .000 \\
\hline & $\begin{array}{l}\text { Penerapan Akuntansi } \\
\text { (X2) }\end{array}$ & 400 & .088 & 269 & 4.523 & .000 \\
\hline & Sistem Pelaporan (X3) & .128 & .055 & .207 & 2.342 & .021 \\
\hline
\end{tabular}

Dari Tabel 8 dapat dijelaskan hasil dari uji regresi linier berganda dan uji hipotesis sebagai berikut:

\section{Hasil Uji Regresi Linier Berganda}

Berdasarkan Tabel 4.18 maka diperoleh persamaan regresi sebagai berikut:

$\mathbf{Y}=0,053+0,401 X_{1}+0,400 X_{2}+0,128 X_{3}$

Keterangan hasil pengujian di atas dijelaskan sebagai berikut:

a. Nilai Konstanta sebesar 0,053 menunjukkan bahwa apabila variabel independen yaitu kejelasan sasaran anggaran (X1), penerapan akuntansi keuangan pemerintan (X2) dan sistem pelaporan (X3), 
dianggap konstan (bernilai 0) maka nilai variabel dependen yaitu Akuntabilitas Kinerja Instansi Pemerintah (Y) adalah sebesar 0,053 .

b. Koefisien regresi $\left(\beta_{1}\right)$ Kejelasan sasaran anggaran (X1), mempunyai nilai positif sebesar 0,401. Hal ini dapat diartikan bahwa setiap kenaikan 1 poin kejelasan sasaran anggaran menyebabkan Akuntabilitas Kinerja Instansi Pemerintah (Y) naik sebesar 0,401 Dengan asumsi variabel lainnya tetap (konstan).

c. Koefisien regresi ( $\beta 2)$ penerapan akuntansi keuangan pemerintah (X2), mempunyai nilai positif sebesar 0,400 . Hal ini dapat diartikan bahwa setiap kenaikan 1 poin penerapan akuntansi keuangan pemerintah menyebabkan Akuntabilitas Kinerja Instansi Pemerintah (Y) naik sebesar 0,400. Dengan asumsi variabel lainnya tetap (konstan).

d. Koefisien regresi $\left(\beta_{2}\right)$ sistem pelaporan (X3), mempunyai nilai positif sebesar 0,128. Hal ini dapat diartikan bahwa setiap kenaikan 1 poin sistem pelaporan menyebabkan Akuntabilitas Kinerja Instansi Pemerintah (Y) naik sebesar 0,128. Dengan asumsi variabel lainnya tetap (konstan).

\section{Hasil Uji t}

Berdasarkan Tabel 8 dapat dijelaskan masing-masing hipotesis sebagai berikut ini.

1. Pengaruh Kejelasan Sasaran Anggaran Terhadap Akuntabilitas Kinerja Instansi Pemerintah (Hipotesis 1)

Hipotesis pertama merumuskan bahwa kejelasan sasaran anggaran berpengaruh terhadap Akuntabilitas Kinerja Instansi Pemerintah. Dari Tabel 4.14 dapat dilihat bahwa t hitung $(5,693)>t$ tabel $(1,985)$, dan nilai sig $(0,000)<(0,05)$, maka kriteria keputusannya adalah $\mathrm{Ha}_{1}$ diterima dan $\mathrm{Ho}_{1}$ ditolak, artinya kejelasan sasaran anggaran berpengaruh terhadap Akuntabilitas Kinerja Instansi Pemerintah. Sehingga dapat disimpulkan bahwa hipotesis pertama $\left(\mathrm{H}_{1}\right)$ diterima.

2. Pengaruh Penerapan Akuntansi Keuangan Daerah Terhadap Akuntabilitas Kinerja Instansi Pemerintah (Hipotesis 2)

Hipotesis kedua merumuskan bahwa penerapan akuntansi keuangan daerah berpengaruh terhadap Akuntabilitas Kinerja Instansi Pemerintah. Dari Tabel 4.14 dapat dilihat bahwa t hitung $(4,523)>\mathrm{t}$ tabel $(1,985)$, dan nilai sig $(0,000)<(0,05)$, maka kriteria keputusannya adalah $\mathrm{Ha}_{1}$ diterima dan $\mathrm{Ho}_{1}$ ditolak, artinya penerapan akuntansi keuangan daerah berpengaruh terhadap Akuntabilitas Kinerja Instansi Pemerintah. Sehingga dapat disimpulkan bahwa hipotesis kedua $\left(\mathrm{H}_{2}\right)$ diterima.

3. Pengaruh Sistem Pelaporan Terhadap Akuntabilitas Kinerja Instansi Pemerintah (Hipotesis 3) Hipotesis kedua merumuskan bahwa sistem pelaporan berpengaruh terhadap Akuntabilitas Kinerja Instansi Pemerintah. Dari Tabel 4.14 dapat dilihat bahwa t hitung $(2,342)>t$ tabel $(1,985)$, dan nilai sig $(0,021)<(0,05)$, maka kriteria keputusannya adalah $\mathrm{Ha}_{2}$ diterima dan $\mathrm{Ho}_{2}$ ditolak, artinya sistem pelaporan berpengaruh terhadap Akuntabilitas Kinerja Instansi Pemerintah. Sehingga dapat disimpulkan bahwa hipotesis pertama (H3) diterima.

\section{Hasil Uji Koefisien Determinasi}

Tabel 9. Hasil Uji Koefisien Determinasi

\begin{tabular}{lcccr}
\hline \multicolumn{4}{c}{ Model Summary } \\
\hline Model & $\mathrm{R}$ & R Square & $\begin{array}{c}\text { Adjusted R } \\
\text { Square }\end{array}$ & Std. Error of the Estimate \\
\hline 1 & $.862^{\mathrm{a}}$ & .743 & .734 & 1.092 \\
\hline $\begin{array}{l}\text { a. Predictors: (Constant), Sistem Pelaporan (X3), Penerapan Akuntansi (X2), } \\
\text { Kejelasan Sasaran (X1) }\end{array}$
\end{tabular}

Berdasarkan Tabel 9 di atas dapat diketahui bahwa nilai Adjusted $R$ Square yang diperoleh sebesar 0,734 atau 73,4 \%. Artinya, kejelasan sasaran anggaran, penerapan akuntansi keuangan daerah, dan sistem pelaporan, dapat mempengaruhi Akuntabilitas Kinerja Instansi Pemerintah sebesar 73,4 \%. Sedangkan sisanya $26,6 \%$ dipengaruhi oleh faktor lain. 


\section{Pembahasan}

\section{Pengaruh Kejelasan Sasaran Anggaran Pada Akuntabilitas Kinerja Instansi Pemerintahan (AKIP).}

Berdasarkan hasil pengujian hipotesis diperoleh bahwa kejelasan sasaran anggaran berpengaruh terhadap Akuntabilitas Kinerja Instansi Pemerintah Kota Pekanbaru. Hal ini menunjukkan bahwa kejelasan sasaran anggaran baik sehingga dapat meningkatkan Akuntabilitas Kinerja Instansi Pemerintah. Ini membuktikan bahwa semakin tinggi kejelasan sasaran anggaran maka akan berdampak pada meningkatnya Akuntabilitas Kinerja Instansi Pemerintah Kota Pekanbaru.

Hasil penelitian ini menunjukkan bahwa untuk meningkatkan Akuntabilitas Kinerja Instansi Pemerintah, OPD perlu menyusun anggaran dengan jelas sehingga kinerja yang diharapkan dapat tercapai. Adanya sasaran anggaran yang jelas, maka akan mempermudah untuk mempertanggungjawabkan keberhasilan atau kegagalan pelaksanaan tugas organisasi dalam rangka untuk mencapai tujuan-tujuan dan sasaran-sasaran yang telah ditetapkan sebelumnya. Hal ini berimplikasi pada peningkatan akuntabilitas kinerja. Kejelasan sasaran anggaran akan membantu pegawai untuk mencapai kinerja yang diharapkan, dimana dengan mengetahui sasaran anggaran tingkat kinerja dapat tercapai.

Berdasarkan teori stewardship, Pemerintah selaku steward dengan fungsi pengelola sumber daya dan rakyat selaku principal pemilik sumber daya. Terjadi kesepakatan yang terjalin antara pemerintah (steward) dan rakyat (principal) berdasarkan kepercayaan, kolektif sesuai tujuan organisasi. Dalam konteks organisasi sektor publik akuntabilitas merupakan kewajiban pemerintah sebagai pemegang amanah (steward) untuk mempertanggungjawabkan kegiatannya kepada rakyat sebagai pihak pemberi amanah (principal) dengan mengungkap segala informasi, baik keberhasilan maupun kegagalan yang dialami oleh organisasi tersebut. Organisasi sektor publik memiliki tujuan memberikan pelayanan kepada publik dan dapat di pertanggungjawabkan kepada masyarakat (publik).

Kejelasan sasaran anggaran berimplikasi pada pimpinan, untuk menyusun anggaran sesuai dengan sasaran yang ingin dicapai instansi pemerintah. Pimpinan akan memiliki informasi yang cukup untuk memprediksi masa depan yang tepat. Sasaran yang jelas akan mempermudah OPD untuk menyusun target anggaran. Selanjutnya target target anggaran yang disusun akan sesuai dengan sasaran yang akan dicapai pemerintah. Oleh karena itu, kinerja sendiri merupakan hasil akhir (output) organisasi yang sesuai dengan tujuan organisasi Putra (2017) menyatakan bahwa penganggaran yang dilaksanakan berdasarakan sasaran sasaran yang jelas tentu akan meningkatkan akuntabilitas kinerja instansi pemerintah dengan didukung oleh adanya partisipasi dalam penganggaran.

\section{Pengaruh Penerapan Akuntansi Keuangan Daerah Pada Akuntabilitas Kinerja Instansi Pemerintahan (AKIP).}

Berdasarkan hasil pengujian hipotesis diperoleh bahwa penerapan akuntansi keuangan pemerintah berpengaruh terhadap Akuntabilitas Kinerja Instansi Pemerintah Kota Pekanbaru. Hal ini menunjukkan bahwa penerapan akuntansi keuangan pemerintah sudah baik sehingga dapat meningkatkan Akuntabilitas Kinerja Instansi Pemerintah. Ini membuktikan bahwa semakin tinggi penerapan akuntansi keuangan pemerintah maka akan berdampak pada meningkatnya Akuntabilitas Kinerja Instansi Pemerintah Kota Pekanbaru.

Hasil penelitian ini menunjukkan bahwa untuk meningkatkan Akuntabilitas Kinerja Instansi Pemerintah, OPD perlu menyusun laporan keuangan daerah sesuai dengan Standar Akuntansi Pemerintah . Jika laporan itu dibuat tidak sesuai dengan standar dan ketentuan yang telah ditetapkan maka laporan itu dapat di mengerti oleh orang. Bagi pemerintah laporan itu adalah hal yang sangat penting karena dengan adanya laporan maka pemerintah akan dengan mudah melihat perkembangan yang terjadi. Laporan yang dimaksud adalah laporan yang sedang terjadi dan laporan keuangan. Laporan itu dapat kita jumpai dari media sosial, media masa dan dari orang yang bersangkutan langsung.

Selain itu menurut pandapat Nordiawan (2006) SAP diterapkan di lingkup pemerintahan, baik di pemerintah pusat dan departemen-departemennya ataupun di pemerintahan daerah dan dinasnya. Penerapan SAP diyakini akan berdampak pada peningkatan kualitas pelaporan keuangan di pemerintahan pusat dan daerah. Oleh karena itu penerapan SAP diyakini akan berdampak pada peningkatan kualitas pelaporan 
keuangan di pemerintahan pusat dan daerah. Dengan demikian informasi keuangan pemerintahan akan dapat menjadi dasar pengambilan keputusan di pemerintahan dan juga terwujudnya transparansi serta akuntabilitas.

Dalam teori stewardship, manajemen pemerintahan dituntut untuk memberikan pelayanan (bertindak sebagai steward (pelayan) bagi kepentingan principal. Dengan demikian manajemen di lingkungan pemerintahan lebih dominan bertindak sebagai steward dibandingkan sebagai agent. implikasi dari teori stewardship yaitu bagaimana pemerintah diberikan kepercayaan dalam melakukan tugas dan fungsinya dengan tepat, merencanakan dan melaksanakan fungsi pemerintahan secara maksimal. Untuk melaksanakan tanggungjawab tersebut ka stewards diharapkan mengerahkan semua kempuan dan sumber daya guna mencapai kinerja yang diharapkan organisasi.

\section{Pengaruh Sistem Pelaporan terhadap Akuntabilitas Kinerja Instansi Pemerintahan (AKIP).}

Berdasarkan hasil pengujian hipotesis diperoleh bahwa sistem pelaporan berpengaruh terhadap Akuntabilitas Kinerja Instansi Pemerintah Kota Pekanbaru. Hal ini menunjukkan bahwa sistem pelaporan yang baik dapat meningkatkan Akuntabilitas Kinerja Instansi Pemerintah. Ini membuktikan bahwa semakin tinggi sistem pelaporan maka akan berdampak pada meningkatnya Akuntabilitas Kinerja Instansi Pemerintah Kota Pekanbaru.

Hidayatullah dan Herdjiono (2015) menyatakan bahwa: Pemerintah selaku pengelola dana publik agar dapat memenuhi akuntabilitas kiranya memperhatikan beberapa hal diantaranya adalah anggaran yang memiliki ciri yakni kejelasan sasaran anggaran, dinana kejelasan sasaran anggaran dapat memudahkan penyusunan target-target anggaran yang sesuai. Pengelolaan keuangan pemerintahan daerah yang berakuntabilitas tidak lepas dari anggaran pemerintah daerah yang digunakan dalam pengelolaan sumber daya dengan baik untuk mencapai kinerja yang menjadi tujuan. Sistem pelaporan diperlukan dalam pertanggungjawaban pengelolaan sumber daya tersebut dengan baik untuk mencapai kinerja yang diharapkan oleh masyarakat dan untuk menciptakan akuntabilitas terhadap masyarakat. Sistem pelaporan merupakan laporan yang menggambarkan sistem pertanggungjawaban dari bawahan (pimpinan unit anggaran) kepada atasan (kepala bagian anggaran).

Teori stewardship menjelaskan eksistensi Pemerintah Daerah sebagai suatu lembaga yang dapat dipercaya untuk bertindak sesuai dengan kepentingan publik dengan melaksanakan tugas dan fungsinya dengan tepat, bertindak secara ekonomis dan efisien dalam penfaatan sumber daya, membuat pertanggungjawaban yang dianahkan kepadanya, sehingga tujuan ekonomi, pelayanan publik upun kesejahteraan masyarakat dapat tercapai secara maksimal. Untuk melaksanakan tanggungjawab tersebut maka stewards dapat menerapkan anggaran berbasis kinerja, mengarahkan semua kempuan dan keahliannya serta menerapkan kepemimpinan yang efektif untuk dapat meningkatkan akuntabilitas kinerja instansi pemerintah.

\section{KESIMPULAN}

Kejelasan anggaran berpe!ngaruh terhadap Akuntabilitas Kinerja Instansi Pemerintah, penerapan akuntansi keuangan daerah berpengaruh terhadap Akuntabilitas Kinerja Instansi Pemerintah dan sistem pelaporan berpengaruh terhadap Akuntabilitas Kinerja Instansi Pemerintah 


\section{DAFTAR PUSTAKA}

Ahyaruddin, M dan Akbar R (2017). Akuntabilitas dan kinerja instansi pemerintah: Semu atau nyata? Jurnal Akuntansi \& Auditing Indonesia, Vol. 21No.2,Desember 2017

Bastian, I (2014). Sistem Akuntansi Sektor Publik, Edisi 2. Jakarta:Salemba Empat.

Cantika, Y (2018). Pengaruh Perencanaan Anggaran, Kejelasan Sasaran Anggaran, Sistem Pelaporan Dan Sistem Pengendalian Internal Terhadap Akuntabilitas Kinerja Pemerintahan Kabupaten Polewali Mandar.

Hidayatullah,A \& Herdjiono (2014) Pengaruh Kejelasan Sasaran Anggaran, Pengendalian Akuntansi, Sistem Pelaporan terhadap Akuntabilitas Kinerja SKPD di Merauke. Unisbank ISBN 978-979-3649-81-8

Khairunsyah dan Yulia E (2018). Pengaruh Kejelasan Sasaran Anggaran, Sistem Pelaporan, Kompetensi Terhadap Akuntabilitas Kinerja Instansi Pemerintah Dimediasi Oleh Komitmen Organisasi (Studi Pada Organisasi Perangkat Daerah Kabupaten Kampar) Jurnal Tepak Manajemen Bisnis, Vol. X. No. 1. Januari 2018.

Mardiasmo. (2012) Akuntansi Keuangan Dasar. Yogyakarta: BPFE.

Donaldson, L. \& Davis, J., (1991). Stewardship Theory or Agency Theory: CEO Governance and Shareholder Returns. Academy of Management Review, 20(1), p. 65.

Mulyadi AR, Syamsidar, \& Efendy. (2019). Pengaruh Sistem Pelaporan dan Kejelasan Sasaran Anggaran Terhadap Akuntanbilitas Kinerja Instansi Pemerintah (Studi Pada Satuan Kerja Pemerintah Aceh). Jurnal Riset Inspirasi Manajemen dan Kewirausahaan. Vol 2. No 2.

Nordiawan, D \& Hertianti, A. ( 2010), Akuntansi Sektor Publik. Edisi Kedua. Jakarta:Salemba Empat

Putra, Andi Perna.. (2017) Determinan Akuntabilitas Kinerja Pemerintah Di Kabupaten Lombok Barat. Jurnal Ekonomi dan Keuangan.

Suyanto, M. Ali Z, (2015). Kejelasan Sasaran Anggaran, Pengendalian Akuntansi, Sistem Pelaporan dan Akuntabilitas Kinerja Instansi Pemerintah pada Inspektorat Jenderal Kementerian Agama RI. Jurnal Riset Akuntansi dan Perpajakan JRAP Vol. 2, No. 1, Juni 2015, hal $89-96$

Yusmaniarti, Yusmaniarti, B. A. (2014). Pengaruh Penyajian Informasi Akuntansi pemerintahan daerah terhadap transparansi dan akuntabilitas publik ( studi pada pemerintahan kota Bengkulu). PPE Press Fakultas Ekonomi Dan Bisnis Universitas Muhammdiyah Surakarta, 563-576.

Zulfiandri, A (2017)..Faktor-Faktor yang memengaruhi Akuntabilitas Kinerja Instansi Pemerintah (Studi empiris pada OPD di Pemerintah Provinsi Banten). Jurnal Riset Akuntansi. JRA Tirtayasa. Vol 2 No 1 (2017) 